\title{
O descumprimento das formas processuais penais como maximização do poder de punir: por uma nova teoria das nulidades ${ }^{1}$
}

\author{
Antônio Tovo Loureiro*
}

\section{INTRODUÇÃO}

O presente trabalho versa sobre a forma processual, mais especificamente a forma processual penal, e os desdobramentos que referida forma ocasiona na prática judicial.

A primeira idéia que logo surge ao versar sobre forma processual é exatamente a teoria das nulidades. A relevância do tema abordado está exatamente no intrincamento de conceitos atinentes às nulidades, seja devido a sua excessiva complexidade, seja devido à multiplicidade de expressões para designar as diferentes circunstâncias, bem como uma infinita gama de princípios, adágios latinos e máximas universais.

Fazendo-se um breve exercício de contraposição entre os julgados que tratam de nulidades com a produção doutrinária realizada em nosso país, o estudioso do direito vê-se sucumbir num oceano de incoerências, impropriedades e de usos que se perpetuam pela simples tradição, embora sejam de racionalidade e de utilidade questionável. Tal discrepância entre a prática judicial e o que se tem escrito sobre nulidades em processo penal, mais que criar uma confusão conceitual dentro da própria teoria, tem notória repercussão no que respeita às garantias do imputado, pelo simples fato de ser ele o sujeito mais débil na relação processual.

Com vistas a buscar uma ruptura com essa tradição formalista inquisitiva, este trabalho objetiva realocar a forma processual, bem como a resposta à sua violação, aproximando dos seus fins no processo, a serviço das funções que realmente exercem. A proposição do

\footnotetext{
* Mestre em Ciências Criminais pela PUC RS e advogado.

1 Artigo originalmente apresentado como monografia para obtenção do título de bacharel em Ciências Jurídicas e Sociais pela Universidade Federal do Rio Grande do Sul.
} 
presente articulado e uma nova perspectiva sobre a reação processual aos atos defeituosos, com inspiração na obra do processualista argentino Alberto Binder. ${ }^{2} \mathrm{O}$ principal postulado de tal teoria é a vinculação das formas processuais às finalidades que desempenham dentro do processo. Para além do academicismo puro, esta proposição surgirá como alternativa viável para elucidar um pouco estes conceitos entravados e com o propósito de efetivar a resposta processual aos seus defeitos.

\section{FUNDAMENTOS DE UMA CULTURA JUDICIAL FORMALISTA: DO PALEOINQUISITÓRIO AO INQUISITÓRIO REFORMADO}

\subsection{Breve panorama}

Com o fito de elucidar como se consolidou o pensamento atual em matéria de nulidades, para que se possa embasar uma crítica nevrálgica a determinados dogmas perpetuados ao longo dos anos que são aqui questionados, imperioso que se busque a origem da cultura judicial de nosso país, identificando alguns pontos da evolução histórica dos sistemas processuais. Ao longo desta breve digressão, acentuaremos de que maneira era vista a forma pro- cessual nestes sistemas. Todavia, esta análise não será feita com o exaustivo aprofundamento que o tema exige, até por não se constituir em nosso objeto central no momento.

No direito romano clássico, existia a noção de que a forma era indissociável de seu conteúdo, e assegurála seria uma forma de tutelar o próprio direito a ela vinculado. Salienta-se que a forma era extremamente importante em vista da característica de oralidade do direito clássico.

As ações penais possuíam caráter privado e eram processadas seguindo um caminho de dialética muito amplo. A acusação e a defesa eram feitas em público, utilizando-se a retórica dos grandes oradores.

Durante o período imperial, viu-se florescer as raízes do inquisitório. Criavam-se magistrados vinculados ao poder central, que eram organizados segundo uma complexa hierarquia de cargos, e cumulavam os poderes de julgar e acusar. Aliada a esta incipiente burocratização, surge um formalismo exacerbado, pois a proteção antes dedicada à palavra falada passa a ser aplicada aos expedientes agora escritos.

Fazendo um salto histórico, na Alta Idade Média verificamos uma predominância do sistema de controvérsia. ${ }^{3} \mathrm{Os}$ juízos de origem visigótica e germânica

2 BINDER, Alberto. El incumplimiento de las formas procesales. Buenos Aires: AD HOC, 2000.

3 LOPES JÚNIOR, Aury. Introdução crítica ao processo penal: fundamentos da instrumentalidade garantista. Rio de Janeiro: Lumen Juris, 2004, p. 151. 
foram continuados nas comunidades feudais da mesma forma que eram realizados entre os povos bárbaros no apogeu de Roma. Primavam pela adversidade, sendo dirimidos pelos líderes locais.

Grosso modo, até o século XIII predomina o sistema acusatório no direito continental, sendo perfeitamente compatível com a fragmentariedade e descentralização do poder político que os feudos produziram.

Com a criação dos tribunais do Santo Ofício, ${ }^{4}$ inaugurados pelo chamado Concilium Lateranensis, no ano de 1215 , o sistema inquisitório passa a sobrepujar gradualmente o acusatório no continente europeu. No mesmo período, há um sensível resgate do ordenamento jurídico justinianeu pelos escolásticos canônicos e notabiliza-se uma retomada do excessivo apego à forma pelo qual preconizava o direito romano tardio.

O nascimento do inquisitório também coincide com um processo de recentralização de poder político pela monarquia, antes disperso entre os senhores feudais. O inquisitório nasce para legitimar a concentração de poder pela Igreja Católica e pela realeza. Dito sistema era perfeito para criar o distanciamento em relação aos súditos, aprofundando seu subjugo.
As características do inquisitório foram abordadas de forma mais detida quando demonstrados os pressupostos teóricos deste ensaio. Apenas para rememorar, cumpre dizer que tratava-se de um sistema escrito, formal, moroso e burocratizado. Ademais, discrepava pela presença de uma pessoa que acumulava todas as funções dos sujeitos processuais, desde a colheita de indícios até o proferimento de sentença final.

$\mathrm{O}$ mito da verdade real ${ }^{5}$ também foi introduzido neste período no âmbito do processo, e isso muito deve-se a sua nebulosa aura metafísica. Os sistemas de dirimição de conflitos até então nunca haviam se concentrado nesta perquirição, a eles bastava a harmonização ser reestabelecida entre os litigantes. ${ }^{6}$ Exatamente com o propósito de chancelar a perseguição ideológica religiosa, é gerado este conceito aberrante, o qual permitia perscrutar a alma do imputado em busca de elementos de culpa. Foi extremamente eficaz para que os inquisidores semeassem o temor entre a população e dissuadissem eventuais insurgentes.

O desenvolvimento do inquisitório prosseguiu em ascensão vertiginosa durante toda a Baixa Idade Média, potencializado pelo advento da imprensa e

\section{Ibidem, p. 159.}

$5 \mathrm{O}$ tema verdade no processo penal merece uma abordagem exclusiva. Trataremos dele como uma falácia engendrada no sistema inquisitório, em nome da qual foi produzida uma infinidade de atrocidades.

6 A respeito do problema da "verdade real" conferir: (DUCLERC, Emil. Prova penal e garantismo: uma investigação crítica sobre a verdade fática construída através do processo. Rio de Janeiro: Lumen Juris, 2004). 
pela injeção de capital nas monarquias, orquestrado pela classe burguesa emergente. Assim, até a Revolução Francesa teremos a vigência do inquisitório em sua faceta mais escancarada. Optamos por denominá-lo de paleoinquisitório.

O código processual de Napoleão é um marco divisor do inquisitório, porque inaugura uma preocupação do princípio inquisitivo com sua roupagem externa, ${ }^{7}$ com o intuito de maquiar seus tópicos mais controversos. Atribui-se esta modificação às inúmeras críticas lançadas ao inquisitório clássico pelos pensadores iluministas.

A astúcia do sistema napoleônico consistiu na incorporação de alguns elementos da tradição jurídica romanogermânica como o juízo oral, por exemplo, mudando acessórios do sistema processual não alterando, no entanto, sua substância. É a criação do inquisitório reformado ou acusatório formal, o qual alguns denominam sistema misto. Não adotamos esta última terminologia por entendermos que acarreta algumas incoerências, haja vista o sistema nunca ser pautado por dois princípios informadores; elementos incompatíveis não conseguem se imiscuir formando um amálgama harmônico.

Com relação ao fenômento do constitucionalismo do século XX, pode-se anotar que forneceu meios para uma compatibilização dos institutos do inquisitório reformado com as normas constitucionais. Deve-se ter em conta que alguns esforços de harmonização são muito prejudiciais, por causarem uma perda de identidade. Uma ruptura com a tradição é muito mais vantajosa nessa espécie de caso, pois cada pensamento foi formulado em uma realidade histórica e sua transposição para outra estrutura será sempre deformadora.

Com efeito, o acusatório formal mantém-se no sistema processual brasileiro até os dias de hoje. O texto constitucional adota um sistema acusatório substancial, mas os intérpretes seguem privilegiando a aplicação de um Código Processual Penal de cunho autoritário. Interpreta-se a Constituição de acordo com a perspectiva do Código Processual.

Destarte, uma das críticas que aqui se tece à cultura jurídica é a perpetuação da vigência de um inquisitório que se mantém arraigado com pequenas adaptações, nunca mudando em seu cerne e que termina por influenciar a concepção de forma processual.

\subsection{A falaciosa teoria geral do processo}

Outra influência nociva em nosso direito processual penal é a de uma teoria geral do processo, tanto civil, quanto penal e até mesmo trabalhista e administrativo.

Uma das raízes desta visão é a influência da obra do jurista italiano Enrico Tullio Liebman, que muda-se para o Brasil no alvorecer do regime de Mussolini e fascinou os processualistas

7 Cfe. BINDER, El imcumplimiento..., p. 46. 
das décadas de 30 e 40 , isto é, na mesma época de elaboração do código - publicado em 1941. Liebman foi defensor da possibilidade de abarcar numa mesma teoria as diferentes disciplinas de processo e aliciou muitos seguidores. Atualmente, no Brasil, o grupo que propugna a possibilidade de uma teoria geral dos processos é denominado de Escola Paulista de Processo.

A doutrina unitária crê possível a uniformização da lógica existente no processo, e acaba subestimando as peculiaridades de cada uma das categorias. Isto é bastante limitador, porque acabam sendo tolhidas as especificidades de cada modalidade, as quais são determinantes e podem modificar completamente a maneira de aplicação da norma. Ademais, há uma constante adaptação de conceitos do processo civil ao penal, ou vice-versa, e nem sempre esse mutualismo é oportuno.

Conforme Jacinto Nelson de Miranda Coutinho, ${ }^{8}$ o processo penal transforma-se em um órfão entre o direito penal e o processo civil.

Num tema complexo como nulidades, a utilização de uma teoria geral unificadora agrava ainda mais a polissemia existente nesse campo, pois surgem novas expressões, oriundas de outros ramos da ciência processual, e vão sendo assimiladas sem a necessária crí- tica. Aí que reside o problema da teoria geral do processo: a solução pensada para o processo civil, possui determinada racionalidade, que não é a mesma do processo penal, e o deslocamento de conceitos cria formas aberrantes.

\subsection{A teoria unitária e suas variantes}

Adotaremos a idéia que Binder ${ }^{9}$ cria de teoria unitária das nulidades, como aquela teoria que pretende unificar todo o tipo de resposta processual ao ato defeituoso baseando-se no binômio forma-violação. A desvantagem deste raciocínio é que ele coloca como meta da resposta a própria forma, e não aquilo a que ela se destina resguardar, em outras palavras, sua finalidade.

A teoria unitária se compreende como a doutrina tradicional que cuida acerca de diferentes casos, princípios e interesses com uma pretensão de uniformizá-los, sob a égide de um raciocínio baseado simplesmente na forma e sua quebra. Carece tal doutrina de um verdadeiro método de análise, principalmente quando busca um conceito de invalidez formal que seja pertinente a todo ato jurídico.

Desta forma, o eixo de discussão cinge-se ao binômio validez-invalidez formal, o que, prima facie, parece bas-

8 COUTINHO, Jacinto Nelson de Miranda. Efetividade do processo penal e golpe de cena: um problema às reformas processuais. In: WUNDERLICH, Alexandre. Escritos de direito e processo penal em homenagem ao professor Paulo Tovo. Rio de Janeiro: Lumen Juris, 2002, p. 140.

9 BINDER, El imcumplimiento... 
tante simples e coerente, num exame mais aprofundado mostra-se uma solução unívoca e obtusa para casos diferentes que envolvem diferentes princípios.

Pode-se pensar que o formalismo excessivo e a teoria unitária são problema recente dos países latino-americanos. Talvez a complexidade crescente da sociedade contemporânea possa ter influído no agravamento deste problema, mas a raiz do problema está no Estado colonial, quando foi instaurado o sistema inquisitório por motivações políticas e quando semearam-se as bases do formalismo. O sistema inquisitório não é apenas uma forma de processo, mas também um modelo completo de organização judicial do Estado Moderno Absolutista, caracterizando-se por ser eminentemente escrito, secreto, formalista, lento, inoportuno, dependente e burocrático. Conforme Jacinto Coutinho, 10 "trata-se, sem divida, do maior engenho iurídico que o mundo já conheceu".

Trataremos de alguns dos pontos basilares deste paradigma como se apresenta nos dias atuais e de algumas das diferentes formas que tomou esta concepção ao longo dos anos.

\subsubsection{Tipicidade processual}

Sustenta-se entre os adeptos da teoria unitária que, à semelhança da tipicidade penal, existiria a categoria de tipo processual," a qual seria um modelo de ato que reúne sujeitos, modelos e circunstâncias definidas pela lei processual.

Caso ocorresse a violação ao tipo, instar-se-ia a respectiva reação processual. Esta classificação permanece investida de uma perspectiva formalista de aplicação das nulidades, característico da ótica restritiva de nulidades, mas percebe-se uma tentativa de agregar a ela alguns preceitos constitucionais deslocados.

Grinover lança mão da tipicidade constitucional, ${ }^{12}$ a qual plasmar-se-ia na desconformidade formal com o texto constitucional. Mais uma vez indaga-se a necessidade desta noção de tipicidade, visto que a invalidez obviamente decorre da violação de preceito constitucional ou legal, não havendo subsunção a ser realizada do ato violador ao preceito afetado. Esta é uma modalidade precipuamente explicativa, que revela-se restritiva, visto que exige previsão no

10 COUTINHO, Jacinto Nelson Miranda. O papel do novo juiz no processo penal. In: COUTINHO, J.N. Miranda (Coord.) Crítica à teoria geral do direito processual penal. Rio de Janeiro: Renovar, 2001, p. 18.

11 BINDER, El incumplimiento..., p. 195.

12 GRINOVER, Ada; FERNANDES, Antonio Scarance; GOMES FILHO, Antonio Magalhães. Nulidades no processo penal. 7.ed. São Paulo: Revista dos Tribunais, 2001, p. 23-24. 
direito positivo para que ocorra a resposta processual.

Além disso, a tipicidade processual não rompe com o formalismo, porque sua análise baseia-se no dualismo violação-formalidade, relegando ao ostracismo a finalidade pretendida.

\subsubsection{Taxatividade}

O legalismo oitocentista plasmou-se no adágio pas de nullité sans texte, visando a restrição dos poderes dos juízes e a coibição dos abusos perpetrados durante o absolutismo, encontrando seu apogeu no Código Napoleônico. Por decorrência desta cláusula, apenas seriam declarados nulos os atos para os quais houvesse previsão de nulidade em texto expresso de lei. Tal perspectiva é própria de uma concepção de presunção de validez da lei e de formas institucionais. ${ }^{13}$

Portanto, a estrutura legalista do critério numerus clausus de nulidades torna-se revestida de um manto ilusório de constitucionalidade, em virtude do fenômeno de constitucionalização do séc. XX. Preconizada como uma forma de atenuar o desgaste jurisdicional, deve ser encarada como um pretexto para dar estabilidade ao trâmite. Em verdade, é muito mais conveniente pensar o sistema de nulidades como vinculado aos preceitos constitucionais, não a uma interpretação restritiva.

No sistema original, selecionava-se hipóteses relevantes de afetação de garantias, indicando-se hipoteticamente atos em abstrato. Isto constituiria uma proteção à lei, ${ }^{14}$ não ao interesse concreto envolvido. O erro em que incidem os propugnadores desta doutrina é de acreditar que o ordenamento tem o condão de abordar absolutamente todas as hipóteses que denotam violação a princípios. Seria um narcisismo processual. ${ }^{15}$

A taxatividade não encontra mais defensores assumidos, mas percebe-se, ao analisar a jurisprudência ou até mesmo trabalhos doutrinários, que remanesce esse temor ${ }^{16}$ de conceder ao magistrado o poder de nulificar atos, pois ausente positivação da hipótese violatória. No entanto, esta situação não é compatível com a figura do juiz garantidor, o qual zelará pelas garantias constitucionais do imputado, prescindindo, para tanto, de previsão em legislação infraconstitucional.

13 BINDER, op. cit., p. 25.

14 Ibidem, p. 27.

15 CARVALHO, Salo de. A ferida narcísica do direito penal. In: GAUER, Ruth (Org.) A qualidade do tempo: para além das aparências históricas. Rio de Janeiro: Lumen Juris, 2004.

16 GRINOVER; FERNANDES; GOMES FILHO, Nulidades... Os autores trabalham com a idéia de legalidade constitucional, mas permanecem vinculados a uma noção restritiva de nulidade, que tem seu fundo no postulado da taxatividade. 
Destarte, a taxatividade deve ser abandonada por ser fruto de uma concepção restritiva de violação de garantias, não podendo ser adotada num sistema garantista-acusatório.

\subsubsection{Pluralidade de termos} descrevendo a matéria

Outro obstáculo que necessita ser superado em nosso sistema, com o intuito de facilitar a reparação dos atos inválidos, é a consolidação da polissemia dos termos que tratam do tema. Pesquisando na doutrina, encontramos, por exemplo: inexistência, ato nulo de pleno direito, nulidade absoluta, relativa, implícita, virtual, saneamento, convalidação, preclusão, impeditiva de argüição, entre outros. Esta pluralidade de expressões não facilita em nada a aplicação deste mecanismo.

Alguns autores apenas agravam esta situação e vão construindo novos conceitos, utilizando um pernosticismo terminológico, próprio de um academicismo exacerbado. Cria-se, portanto, uma gama infindável de termos para designar os mesmos conceitos, ou pior, constroemse conceitos desnecessários, vazios.

A idéia deste trabalho é propor uma depuração neste âmbito, eliminando-se os conceitos inúteis da teoria da invalidez dos atos processuais. O objetivo disto é eficientizar a resposta processual aos vícios, despindo-a de toda a pompa que se faz em torno dela, tendo em mente o caráter eminentemente instrumental do direito processual.

\subsubsection{Imprecisão sobre o conceito} de nulidade e nulidade como sanção do ato imperfeito

Se há nebulosidades sobre o próprio conceito do objeto, é evidente que toda a teoria que se encadeará sobre este conceito será inconsistente. Em nosso país, a dogmática não faz uma delimitação clara $^{17}$ no que consiste a nulidade, sendo o termo utilizado tanto para designar o ato reputado defeituoso quanto a resposta judicial à invalidez, assim como a teorização que se realiza a respeito de ambas.

O Código de Processo Penal incorpora esta imprecisão, usando o termo nulidade tanto para designar a decisão judicial que nulifica o ato quanto a violação formal, v.g.: "A nulidade ocorrerá nos seguintes casos: I - por incompetência, suspeição ou suborno do juiz; [...]". ${ }^{18}$ Note-se que a nulidade não ocorrerá nos casos enumerados, contudo, o ato será irregular nas hipóteses previstas. Com efeito, a nulidade só ocorrerá após um ato judicial que decrete que $o$ ato processual inquinado não pode gerar os efeitos a que se destinava.

Indubitavelmente, esta confusão entre a decisão judicial e o ato defeituoso é extremamente prejudicial, pois geradora de uma incerteza acerca de qual das acepções se está invocando.

17 BINDER, El incumplimiento..., p. 32.

18 Código de Processo Penal, art. 564. 
Se tudo é denominado nulidade, não se compreenderá ao certo no que consiste. Tal incerteza é um fator de risco, em se tratando de proteção ao acusado.

Outra noção que cumpre criticar é de nulidade enquanto sanção ${ }^{19}$ do ato defeituoso. ${ }^{20}$ Julio B. Maier ${ }^{21}$ faz uma das maiores críticas a este entendimento, refutando a declaração de nulidade como imposição de uma sanção.

O argumento de Maier é peremptório: as sanções presumem a conexão a um prejuízo, senão para o infrator, ao menos para um terceiro. Maier defende ainda que a nulidade não é uma sanção nem do ponto de vista formal, nem material, sendo que considerar-se-á nulo apenas o antônimo de válido, caracterizando o ato como inidôneo. Textualmente:

Juridicamente, sin embargo, el concepto de nulidad es totalmente neutro, esto es, no representa de por si ningún perjuicio o benefício, sino una crítica a la acción llevada a cabo incorrectamente $y$, por ello, incapaz de producir el efecto que la norma le asigna. (Sem grifos no original).

Para além do preciosismo semântico, desfazer o mito de nulidade como sanção ocasiona efeitos mais concretos do que possa parecer prima facie. A idéia de sanção está investida de uma carga axiológica que tem repercussões no caso concreto.

Os atos defeituosos, se entendidos como sanção processual, passam a ser parâmetro de qualidade dentro da administração das burocracias judiciais. Quanto menos defeitos houver, melhor será a vara ${ }^{22}$ ou o tribunal. Mais uma vez, teremos um fator de incremento do excessivo apego à forma entre os funcionários do judiciário. Desta forma, contribui-se de uma maneira quase subliminar para o esquecimento do papel que está a cumprir a forma dentro daquele contexto.

19 RANGEL, Paulo. Direito processual penal. 10. ed. Rio de Janeiro: Lumen Juris, 2005. "Nulo é o ato defeituoso, atípico, que sofreu a sanção de nulidade." O autor mostra-se neste trecho alinhado tanto à doutrina de tipicidade processual quanto à conceituação de nulidade enquanto sanção. Frederico Marques (Elementos de direito processual penal. 2.ed. Rio de Janeiro: Forense, 1965. V. II p. 397 ), Tornaghi (Instituições de direito processual penal. São Paulo: Saraiva, 1977. V. II, p. 47) e Tourinho Filho (Manual de processo penal. São Paulo: Saraiva, 2001) partilham da mesma posição.

20 A nulidade é tratada como sanção processual em nosso Código de Processo Penal. Francisco Campos, em sua exposição de motivos - inciso XVII -, invoca escólio de um processualista italiano, do qual não revela o nome: "Um bom direito processual penal deve limitar as sanções de nulidade àquele estrito mínimo [...]".

21 MAIER, Julio B. J. La función normativa de la nulidad. Buenos Aires: Depalma, 1980, p. 129-133.

22 No mesmo sentido, embora com argumentos diferentes, posicionam-se TOVO, P.C. Nulidades no processo penal hrasileiro: novo enfoque e comentário. Porto Alegre: Fabris, 1988, p. 15-16. 
Trataremos da natureza da nulidade segundo a teoria adotada por este trabalho no capítulo oportuno.

\subsubsection{Nulidade da forma pro-} cessual como nulidade do ato jurídico

A última das críticas lançadas aos dogmas da teoria unitária será à noção que permeia a concepção de nulidade em matéria processual penal, e que está relacionada à vigência de uma errônea teoria geral do processo, é que a nulidade da forma processual é percebida da mesma maneira que a forma do ato jurídico. Esta noção é transplantada da teoria de nulidades em direito privado, no qual a forma presta-se a preservar a declaração de vontade.

Esta noção está muito arraigada na doutrina brasileira. Rangel ${ }^{23}$ estabelece que "o ponto de partida de nosso estudo é $o$ ato jurídico". O núcleo fundante para o autor em matéria de nulidades no processo penal é a definição de ato jurídico do Código Civil.

Conforme Binder, ${ }^{24}$ as formas jurídicas eram comuns aos atos jurídicos, por serem vinculadas no Direito Romano, a assegurar a manifestação da vontade, em decorrência do caráter verbal do ordenamento clássico. Entretanto, no inquisitório, que se consolida em sua forma mais caricata no século $\mathrm{XVI}$, esta idéia permanece sendo pro- palada, quando, em verdade, não existia a mesma correspondência. Os tribunais passam a se afirmar como estruturas autogeridas, com rotinas específicas; ademais, sua finalidade não mais é apenas a dirimição de conflitos, pois assumiram metas próprias. A forma processual assume uma nova função diferente da que possuía no direito romano, e os juristas permanecem repetindo cegamente que a forma processual serviria à proteção da declaração da parte.

A relevância da proposta que Alberto Binder realiza - e que é adotada neste articulado - é de realizar uma conexão da forma com a prática judicial, deixandose de reputá-la exsurgente do ato jurídico, com o fito de poder refletir-se sobre as distintas funções da forma e distintas maneiras de resposta à sua violação.

\section{FUNDAMENTOS PARA UMA NOVA TEORIA DA REAÇÃO AO QUEBRANTAMENTO DE FORMAS}

Conforme já referimos, a doutrina sobre nulidades acaba desorientando o aplicador e o estudioso do tema. Isto evidencia-se quando as conceituações são elaboradas à base de analogias formais ou similitudes semânticas, acabando por ocultar problemas centrais e transpor princípios inadequados e distorcidos.

\section{RANGEL, Direito..., p. 723.}

24 BINDER, El incumplimiento..., p. 41. Binder esclarece que pode ser encontrada uma similitude entre os institutos jurídicos, já que descendem do mesmo ramo. Entretanto, esta distinção será significativa por atrelar o uso do trâmite pelo poder judicial e emancipar a forma da função que possuía anteriormente e das funções que cumpre no processo contemporaneamente. 
Segundo a exposição realizada, estes são desdobramentos do desenvolvimento histórico do sistema inquisitório, em seus variados estágios, e de classificações deficitárias, centradas em impróprias idéias de uma teoria geral do processo, ou mesmo da teoria unitária das nulidades. Um dos fatos mais pungentes com relação a isto é que percebe-se que os operadores do sistema acabam tentando tirar proveito dessas indefinições, ora protelando pelo ritualismo, ora deixando de reconhecer vícios de forma relevantes, em nome de um metafísico interesse público ${ }^{25}$ ou da celeridade processual.

Portanto, com fulcro nos ensinamentos do jurista argentino Alberto Binder, ${ }^{26}$ realiza-se proposição de uma simplificação e eficientização da maneira que o sistema processual reage à invalidez de seus próprios atos. Para tanto, buscaremos depurar e tornar mais visíveis as distintas funções desse mecanismo de resposta aos atos inválidos. Como transparece pelo exame da própria doutrina, este é um dos temas mais intrincados em direito processual e sobre o qual se realizam teorizações empoladas, que só geram maiores entraves no momento de aplicação.

Outra grande limitação que acomete o direito processual penal brasileiro é a ausência de codificação suficiente de normas teóricas e sistematizantes que consolidem um sistema com base na teoria das nulidades. Existem cinco artigos no Código de Processo Penal ${ }^{27}$ (arts. 563, 565, 566, 572 e 573) realizando disposições gerais para disciplinar a matéria e os demais versam acerca de hipóteses abstratas nas quais deve ser declarada nulidade. Foi aberto um espaço demasiado amplo para a construção dogmática, a qual foi sendo feita de maneira completamente caótica e sem princípios informadores bem definidos - certamente não são os mesmos da teoria que aqui se propõe.

A construção doutrinária foi preenchendo as vaguezas com base nos postulados do direito processual civil, o qual estabelece-se em marcos contrapostos à doutrina penal. Em vista do período de elaboração do texto legal, também estão muito presentes a cultura inquisitória e um paradigma autoritário de defesa social. ${ }^{28}$

25 GRINOVER; FERNANDES; GOMES FILHO, Nulidades... lecionam que passa-se de uma noção de direitos fundamentais individualista para uma perspectiva transindividual, calcada no interesse público. Apenas deve-se ter em conta que o interesse geral é muitas vezes fundamento das restrições impostas às garantias do imputado pela jurisprudência, sempre invocado como um elemento abstrato, sem demonstração.

26 BINDER, op. cit.

27 GRINOVER; FERNANDES; GOMES FILHO, Nulidades..., p. 28. Os autores referem a excessiva abertura pela qual optou o legislador, mas consideram que os princípios plasmados em lei bastam para que se sedimente um sistema de nulidades congruente.

28 CARVALHO, Salo de. Pena e garantias. 2.ed. Rio de Janeiro: Lumen Juris, 2004. 
Caso se observe a exposição de motivos do Código de Processo, firmada por Francisco Campos, verificar-se-á a menção aos etéreos direitos do Estado de combate à criminalidade, evitandose o "rigoroso formalismo". ${ }^{29}$ Este é o paradoxo enfrentado pelo sistema processual, porquanto compactua-se com a supressão de meros formalismos - leiase garantias do imputado - e, em contrapartida, protege-se a prática institucional.

A presente proposição evitará o incurso em um neoformalismo, tendo o cuidado de efetivamente romper com a vetusta teoria tradicional. Ressaltamos que segundo o presente prisma a forma não possui valor intrínseco, só será pertinente sua proteção quando a ela estiver tutelado o princípio que visa a proteger.

O essencial para começar o afastamento da teoria tradicional das nulidades é realizar uma mudança do eixo segundo a forma do ato processual é costumeiramente abordada e aproximá-la da função que ela exerce. O objetivo é propor uma teoria em consonância com as funções da forma processual e considerá-las de maneira determinante para a estruturação de uma eficiente resposta a violação de requisitos legais e encadeamentos de atos.

\subsection{Reconceituação da nulidade}

Binder $^{30}$ apresenta-nos a indelével necessidade de elucidar qual a precisa extensão dos institutos relacionados com a resposta ao descumprimento formal, com o propósito de elucidar-se sua pertinência e adequação. Os conceitos que mais são citados dentro da disciplina são, sem embargo, o saneamento, a convalidação e a nulidade. Todavia, constrói-se toda uma estrutura tendo como eixo principal a nulidade, quando esta deveria ter um significado residual, o que significa dizer que a nulidade deveria ser a ultima ratio, recebendo seu conteúdo significativo a partir da conceituação de outras soluções processuais ao ato imperfeito.

Esta lógica apresenta-se em todo o pensamento do precitado autor e encontra guarida nos ensinamentos de Luigi Ferrajoli. Não podemos esquecer, contudo, que o formalismo, isto é, a defesa da forma pela forma, com um valor intrínseco, acaba por sobrepujar a liberdade.

Michel Foucault ${ }^{31}$ realiza uma ampla análise acerca da prática política institucional, sendo relevante, para nosso objeto, a rotina dos tribunais. A prática judicial seria o meio pelo qual formam-se sujeitos de conhecimento e relações de verdade. $\mathrm{O}$ valor da forma em si, a forma pela forma, foi uma criação da cultura ritualista, a qual desagrega a forma processual da função que ela exerce no processo, passando a tutelar o expediente.

29 Exposição de motivos do CPP, incisos XVII e XVIII.

30 BINDER, El incumplimiento..., p. 32.

31 FOUCAULT, Michel. A verdade e as formas jurídicas. 3.ed. Rio de Janeiro: Nau, 2003, p. 27. 
Pretendemos passar a idéia de um formalismo compreendido como a centralização do expediente no cotidiano forense, as diferentes maneiras de exercer poder pelo trâmite, a subsistência de formas extintas ou inadequadas. A cultura judicial somada à prática formalista constitui um dos maiores entraves ao repensar jurídico neste objeto.

\subsection{A teoria funcional das nulidades}

A análise unitária realiza uma consideração pobre e formal dos conceitos fundamentais, com reduzido grau de crítica. Conforme visto no capítulo anterior, isto também é herança de uma falsa harmonia ${ }^{32}$ entre os atos jurídicos e os requisitos legais dos atos processuais, a qual realiza uma distorcida equiparação entre fenômenos jurídicos completamente diversos, elegendo isto como premissa fundante, desconsiderando plenamente a prática institucional.

Postularemos o abandono da análise unitária, reconhecendo-se que não é possível transpor temas e problemas dos atos jurídicos para as formas processuais, e explorar as consequiências deste abandono. Seguindo a linha mestra da teoria esboçada por Binder, lançamos uma proposta de reação processual à invalidez fulcrada nas três funções precípuas $^{33}$ que as formas processuais penais podem cumprir:

a) proteção do sistema de garantias, porquanto as formas procederão à salvaguarda do imputado em face do poder penal. Neste âmbito, as formas são encaradas como mecanismos de proteção;

b) promover a institucionalização do conflito, ou seja, limitar a tutela judicial do direito da vítima;

c) implementar a objetividade da atividade do Ministério Público, ou seja, restringir as prerrogativas legais do acusador estatal para ordenar a defesa dos interesses da vítima. ${ }^{34}$

Será verificada muitas vezes, quando da análise do caso concreto, a existência de um antagonismo entre os três distintos interesses citados. Para que se possa facilmente ultrapassar eventuais contradições, é necessário ter-se em mente a escala de valores que gradua estas funções na seara processual penal. Sem embargo, haverá uma preponderância das garantias do imputado sobre as de-

32 BINDER, El incumplimiento... Uma das grandes preocupações do autor é com a pretensão que os operadores do direito possuem de harmonizar diversos conceitos, os quais, no mais das vezes, não são harmonizáveis, tampouco, convenientes de se traçar uma correspondência, que acaba sendo artificial, com a agravante de ocultar certas peculiaridades.

33 Ibidem, p. 43. O argentino faz uma colocação muito arguta: se não forem bem definidas as funções das formas processuais, elas passarão a defender a rotina institucional.

34 Ibidem, p. 50. 
mais finalidades, consoante toda a base epistemológica de um processo penal garantista. Esta é a lógica que deve reger a solução de atritos entre as funções.

Podemos observar que, sob a égide da teoria unitária, nesta dirimição de conflitos utiliza-se um falso paternalismo processual, que nada mais é senão a utilização de um argumento supostamente em favor do imputado, quando, em verdade, pretende-se efetivamente prejudicá-lo. No campo dos atos inválidos, está em jogo o interesse concreto do imputado e esta será a baliza da resposta processual. Contudo, o imputado não pode obrigar o Estado a atuar de maneira irrazoável. ${ }^{35}$

Quanto à teoria tripartite que ora se adota, reconhecemos que até seria possível reduzir suas três modalidades a uma única teoria, pela mera criação de uma categoria classificativa superior, uma raiz comum. Binder alerta que isso é indesejável, em virtude daquilo que ele denomina de falácia idealista do pensamento jurídico; o jurista sofre da síndrome de categorizar e conceituar em grandes núcleos, imbuído dos auspícios de simplificar a aplicação do ordenamento. O malefício desta ten- dência é que se insufla uma superficialização do pensar crítico, que é uma síndrome bastante comum na ciência jurídica, dando-se espaço a uma nova distorção da teoria.

\subsection{A proteção do sistema de garantias}

A partir da propositura de deslocamento do eixo de uma concepção puramente formal do ato inválido para uma teoria substancial ou funcional, estruturaremos a primeira das funções da teoria proposta, que é a resposta processual aos atos que violem requisitos legais e cadeias de atos que pretendam realizar a proteção do imputado.

Há uma distinção relevante que deve ser realizada antes do detaIhamento desse âmbito. Uma importante conceituação que Binder refere en passant e que é influência da obra de Ferrajoli em seu pensamento será importante para a proposição de seu pensamento. Ferrajoli ${ }^{30}$ dissocia garantia de direito, aduzindo que o princípio pode até ser reconhecido pelo texto constitucional ou por tratado internacional, mas entre seu reconheci-

35 "El imputado no es dueño del proceso [...]. No puede pretender ser juzgado de por fuera de las condiciones de legitimidad del Estado de derecho." De fato, não se está a pregar aqui uma vantagem extraprocessual ao réu. Apenas se pretende uma eficácia máxima da estrutura de tutela do débil, o que não significa, em nenhuma hipótese, garantir-lhe privilégios que possam contrariar as próprias condições de legitimação do processo penal. 36 FERRAJOLI, Luigi. Derechos y garantias: la ley del más débil. Traducción Perfecto Andrés Ibáñez. Madri: Trotta, 2001. p. 59. 
mento e sua garantia há uma grande distância. Textualmente:

Es claro que si confundimos derechos y garantías resultarán descalificadas en el plano jurídico las dos más importantes conquistas del constitucionalismo de este siglo, es decir, la internacionalización de los derechos fundamentales y la constitucionalización de los derechos sociales, reducidas una y otra, en defecto de las adecuadas garantías, a simples declamaciones retóricas o, a lo sumo, a vagos programas políticos jurídicamente irrelevantes. (O grifo é nosso).

Binder realiza uma pequena adaptação e trata o mesmo conceito de direito fundamental como princípio. Segundo sua tese, garantia é a estrutura que concretiza a vigência do princípio. O desdobramento que isto terá em nosso mote é que o princípio só estará garantido quando o ato que o afeta enceta sua privação de conseqüências jurídicas.

Concebemos as formas processuais enquanto requisitos legais dos atos ou sequiencias de atos, os quais objetivam a proteção de princípios do ordenamento jurídico. Em determinado momento de sua obra, Binder chega a defender que a adequação do sistema processual ao conjunto de princípios do Estado é a medida do grau de garantia a eles conferida. ${ }^{37}$
Dentro de sua peculiar teoria, Binder vincula ao tema das formas processuais a questão do processo cognitivo e da verdade no processo penal, considerando-as indissociáveis das formas e dos princípios do processo, bem como indispensáveis para que se compreenda o regime das nulidades no processo penal. Em virtude destes temas exigirem um trabalho à parte para sua abordagem, referiremos perfunctoriamente a idéia do autor para que se tenha um panorama de sua extensão.

\subsubsection{As meras irregularidades e} defeitos substanciais

Essencial para a análise da proposta de Binder é entender que o cumprimento das formas não é um fim em si mesmo, mas sim uma atividade meio para garantia do respeito aos princípios imbricados no ato processual. Quando da ocorrência de violação da forma, deve-se preconizar pela restauração do princípio afetado, ${ }^{38}$ e não pelo mero restabelecimento da forma.

Binder postula que existe uma macroestrutura de garantias processuais, as quais sustentam os princípios. Seria um nível superior de garantia, o qual encontra-se em comunicação com os princípios e assegura sua efetividade. Existe ainda uma microestrutura de

37 BINDER, El incumplimiento..., p. 58.

38 BINDER, El incumplimiento..., p. 85 "Pareciera que se presupone el conocimiento de la función de las formas o se asume que esa función no es problemática y por ende no necesita ser esclarecida." A função das formas é tratada como obviedade, e é esquecida pela doutrina e pela prática dos tribunais. 
garantias,${ }^{39}$ formada pelos atos e requisitos legais, nos quais consiste a concreção da macroestrutura. As duas modalidades de categorias são essenciais para impedir uma interpretação isolada das garantias e princípios, bem como serão de fundamental importância para a atividade judicial de restauração. Ademais, pensar macroestrutura independente de micro seria incorrer numa metafisica dos princípios; a microestrutura desvinculada da macro transformar-se-ia com facilidade em um neoformalismo.

Uma das grandes falhas, segundo Binder, na qual se incorre com freqüência é a transformação de todo e qualquer defeito formal em invalidez, o que parece uma visão obtusa, haja vista não considerar a totalidade de garantias envolvidas em conjunto no ato. Este foi um dos motivos que levou os legisladores napoleônicos a optar pelo sistema legal taxativo de nulidades, de maneira a atar as mãos do magistrado.

O sistema de garantias possui dimensão essencial nas formas processuais, ao impedir que estas sejam consideradas meramente em sua transgressão ou com um viés formalista. A partir da noção funcional, surge a idéia da preponderância do objetivo e função da forma em detrimento da forma pela forma, como valor em si.

Reiteramos que o ritualismo, no sistema inquisitório, não consistia em um apego inocente à forma, mas sim em uma modalidade ideológica de exercício do poder pelo trâmite. Não obstante, em nosso sistema judicial, o formalismo ainda cumpre papel de barreira contra a excessiva quantidade de feitos que abarrotam os gabinetes da magistratura. Estes são os fatores da sacralização do expediente $^{40}$ que impera em nossos tribunais, e que resultam no sem número de formas vazias, os quais configuram nítidos padrões de adaptação da cultura inquisitiva aos estados republicanos.

O formalismo gera duas espécies de profissionais dentro dos tribunais: o cartorário formalista e o juiz-burocrata. O funcionário, permeado pela cultura inquisitiva reformada, torna-se um fiscal do trâmite; o juiz deixa de exercer a judicatura para preocupar-se com atividades menores de administração do expediente. Este é o retrato do acusatório formal.

\subsubsection{Espécies de respostas aos} atos defeituosos

Primeiramente, quando falamos da reação processual aos atos que tiveram sua forma descumprida, cumpre mencionar que a forma processual não será garantia do cumprimento do princípio a que se propõe, mas sim facilitadora de sua vigência, bem como geradora de um "alerta" que facilita a restauração.

Com o fito de simplificar, esclarecer certos pontos nebulosos dessa disciplina,

39 lbidem, p. 73.

40 Ibidem, p. 112. 
surge o conceito de resposta ao ato defeituoso como a atividade jurisdicional que visa à reparação de princípio, reconhecimento de que a ruptura formal não agrediu princípio ou declaração de que o ato não tem condão de produzir efeitos. Deste conceito inferem-se três desdobramentos ${ }^{41}$ da teoria do ato defeituoso: (a) o quebrantamento de formas nem sempre gera ato inválido, embora este seja sempre irregular; (b) a invalidez do ato nem sempre acarreta nulidade, visto que a invalidez pode ter se reparado por si mesma ou pelo poder judicial; (c) a nulidade dos atos só deve ser declarada como solução extrema aos atos impassíveis de restauração.

$O$ ato inválido que fere princípio de garantia ensejará a reação processual que vise a saná-lo, seja por meio do saneamento, seja pela nulidade propriamente dita.

O saneamento consiste, destarte, no restabelecimento de princípio constitucional que foi violado pela atividade processual defeituosa. Não se deve confundi-lo, ainda com o mero restabelecimento da forma, o qual pode ocasionar prejuízos ainda mais graves ao imputado. O saneamento não estaria vinculado também à atividade defensiva, porquanto prescinde de alegação, podendo ser realizado ex officio pelo juiz, visto que se inclui entre as atividades ínsitas à jurisdição. Tal atividade oficiosa, distante da arbitrariedade, sofre limitações pelo interesse em concreto do imputado e pelos casos em que a quebra da forma foi irrelevante - esta última hipótese deve ser interpretada com extrema cautela.

O saneamento é o ponto central do sistema de reparação de atos inválidos no sistema de garantias, esvaziando-se a esfera que detém a nulidade na teoria unitária.

A partir da teoria funcional, tornase sem utilidade a tradicional distinção entre nulidades relativas e absolutas, visto que não há espaço para a convalidação sob a égide do sistema de garantias. Portanto, não haveria nulidade "relativa", ou seja, passível de restauração automática em nome de princípio superior-em direito processual penal, não há princípio superior à garantia do imputado. Ademais, como bem ressalva Binder, a idéia de nulidades relativas, em contraposição às absolutas, cria ilusório nexo de correspondência entre a nulidade do ato jurídico e a nulidade da forma processual, já criticada neste trabalho.

A propósito da convalidação, positivada no Código de Processo Penal em seu art. 572, ${ }^{42}$ não há compatibilidade de tal resposta processual com o sistema de garantias, visto que ela pressupõe que o vício formal do ato será ignorado em favor de interesse maior que as próprias

41 BINDER, El incumplimiento..., p. 96.

42 Art. 572. As nulidades [...] considerar-se-ão sanadas: [...] II - se, praticado de outra forma, o ato tiver atingido seu fim; III - se a parte, ainda que tacitamente, tiver aceito seus efeitos. 
garantias do acusado. Para esta teoria, não há princípio superior à tutela do imputado.

Portanto, para reger a reação processual às formas inválidas sob o prisma do sistema de garantias, basta utilizar os conceitos de reparação e nulidade, de maneira a reduzir a excessiva quantidade de termos usualmente empregados nessa disciplina.

Outra noção a ser abandonada nesta seara é a preclusão, ou seja, a absorção do prejuizo em virtude do transcurso de tempo ou não alegação em determinado marco processual. Parece inadequado pensar que o tempo impedirá a reparação do vício processual.

Por fim, não possuem o condão de afastar a lesão ao manto protetivo do acusado as alegações de consentimento explícito, tácito ou de ato provocado pelo próprio imputado, vez que não é viável exigir-se do réu a coerência entre seus atos. Respaldando essa afirmativa está o CPP Modelo para a IberoAmérica, o qual positiva a regra de não invocar-se a torpeza do defendido para eximir-se de declarar nulidade. ${ }^{43}$

\subsubsection{A nulidade}

A definição de Binder de nulidade resume-se em perda de efeitos próprios de ato processual por sua realização defeituosa. O conceito, que é flagrantemente simples, não deveria dar margem à elaboração de uma teoria entravada, repleta de vaguezas e contradições, conforme foi sendo realizado na teoria unitária.

Aqui também se faz conveniente uma crítica, quanto ao uso do termo anulável dentro do direito processual penal, pois é um conceito tipicamente de direito privado, não considera uma decisão após atividade estatal institucionalizada, é pertinente apenas num direito estabelecido entre particulares. Não haverá disponibilidade do defeito, em havendo afetação de princípio, o qual a parte argüirá ou não conforme sua própria conveniência. Por estes motivos, não é um termo conveniente para designar graus de invalidez do ato.

A resposta nulificadora tem diversos graus, além de diferentes extensões conforme a quantidade de atos que estão encadeados em um mesmo caminho processual.

O primeiro escalão seria a mera desconsideração da informação produzida pelo ato. Nesta modalidade, por consectário lógico, a declaração de nulidade ensejaria a eliminação física do ato, ou seja, seu desentranhamento dos autos do expediente. Se o ato não produziu efeitos, não haveria razão para mantê-lo nos autos a não ser um ritualismo excessivo. Se o juiz deve desconsiderá-lo, como se pode ter certeza que deixará de valorar ato nulo que não foi desentranhado dos autos, ainda que de forma velada, à solércia?

43 Combate-se a posição do CPP em seu art. 565: "Nenhuma das partes poderá argüir nulidade a que haja dado causa, ou para que tenha concorrido, ou referente a formalidade cuja observância só à parte contrária interesse." 
3.3.4 A controversa questão do prejuizo na jurisprudência no sistema brasileiro: inversão do ônus probatório

Em matéria de nulidades no processo penal brasileiro, cristalizou-se o aforismo do pas de nullité sans grief. A utilização do parâmetro prejuizo é efetivamente útil para que não se incorra no formalismo de decretar nulidade em virtude de qualquer irregularidade, o que flagrantemente acarreta prejuízo ao imputado. O Código de Processo Penal materializa esta regra em seu artigo $563 .{ }^{44}$

O adágio é coerente com uma teoria ampla de descumprimento formal, que propugna algo além da atribuição de valor intrínseco à forma processual.

Não obstante, como sói ocorrer, a prática dos tribunais distorceu a questão do prejuízo, em virtude da ausência de uma sistematização ampla da reação processual à invalidez, e também em decorrência de toda cultura de que está investido o poder judicial. A inversão que ocorreu é bastante grave: onera-se o débil com a carga de comprovar o prejuizo ocorrido. O acusado, além de possuir menos condições materiais de juntar elementos que convençam do dano efetivo a suas garantias, nem sempre conseguirá realizá-lo, porque talvez simplesmente não seja possível. O dano a uma garantia, ou a um princípio, nem sempre é passível de comprovação material.
Grinover $^{45}$ propõe uma visão um pouco diferente: a dissociação entre prejuízo evidente e prejuízo que demanda demonstração. A idéia que os autores esposam é a seguinte:

Já com relação às nulidades relativas, o mesmo não ocorre; aliás, um dos traços distintivos entre estas e as absolutas consiste exatamente na exigência de demonstração do prejuízo; nas nulidades absolutas, essa tarefa é desnecessária, pois a natureza da irregularidade evidencia o dano à parte ou à decisão judicial; nas chamadas nulidades relativas, o prejuizo não é constatado desde logo, em razão do que se exige alegação e demonstração do dano pelo interessado no reconhecimento do vício. (Sem grifo no original).

Ainda que aceitássemos a distinção entre nulidades relativas e absolutas, a qual é refutada neste estudo, cumpre apontar uma falha mais grave no entendimento de Grinover. Há uma abertura excessiva nos casos em que é necessário demonstrar o prejuízo, pois apenas atrela-se a necessidade de demonstração do prejuízo ao fato de constituir a hipótese uma nulidade relativa note-se, mais uma vez, a confusão entre ato inválido e a decisão nulificadora. A falha deste raciocínio é que não há previsão explícita de quais atributos a violação deve possuir para que seja digna

44 Art. 563: "Nenhum ato será declarado nulo, se da nulidade não resultar prejuízo para a acusação ou para a defesa."

45 GRINOVER; FERNANDES; GOMES FILHO, Nulidades.., p. 29-30. 
de nulidade absoluta, e de transferir à parte (qualquer que seja) o ônus de demonstrar o prejuízo.

Ressalta-se que o Código de Processo Penal não realiza esta distinção absolutas/relativas, apenas assinala hipóteses de preclusão e de convalidação. Outro óbice ao entendimento aos professores das Arcadas é que nem todas as hipóteses ensejadoras de nulidade estão previstas em lei. Portanto, resta ao magistrado determinar em que consiste a nulidade relativa.

A vulnerabilidade deste viés é, destarte, a vagueza da chamada nulidade relativa. O poder judicial pode incluir nesta esfera aquilo que the convier, eximindo-se da reparação do vício porque não foi devidamente demonstrado.

Um exemplo emblemático da conivência do Judiciário com as violações ao escudo protetivo do réu está evidenciado na súmula $n^{\circ} 523$ do Supremo Tribunal Federal:

No processo penal, a falta de defesa constitui nulidade absoluta, mas a sua deficiência só o anulará quando houver prova de prejuízo para o réu.

Parece clara a ideologia presente no entendimento do STF. O réu será lesado tanto pela deficiência de defesa quanto pelos juízes que o farão comprovar que realmente sofreu prejuízo. A mentalidade dominante em nossos tribunais é do equilíbrio do trâmite, ${ }^{46} \mathrm{e}$ reparar um princípio de proteção do acusado, ainda que tenha status constitucional, seria romper com a suposta estabilidade. Há uma enorme discricionariedade para a definição do limite absoluta/relativa, e os juízes que compactuam com o formalismo inquisitivo incluem na segunda categoria os casos nos quais não querem dar a resposta nulificadora - pois sabem que é praticamente impossível comprovar dito prejuízo.

Conforme explanado, a discrepância entre nulidades relativas e absolutas não se coaduna com a teoria aqui advogada. No que diz respeito ao prejuízo, é necessária uma inversão do pensamento. Quando se reputava necessária a comprovação deste prejuízo pelo acusado, estava-se distorcendo o sistema. Obrigar o acusado a comprovar equivalia a negar-lhe a vigência do interesse concreto danificado.

Devemos ter em mente que, nos casos de descumprimento de formas que impliquem violação a princípios de tutela do imputado, vige uma presunção de prejuizo ${ }^{47}$ Caberá sim a demonstração de que o prejuízo não ocorreu para que o defeito não seja reparado.

\subsection{Formas processuais e a atividade acusatória}

A principal função da forma processual, é, sem dúvida, de proteger o imputado. Esta é a idéia central que

46 BINDER, El incumplimiento..., p. 25, nota 20.

47 BINDER, El incumplimiento..., p. 30. 
deverá pautar o exame da violação formal em se tratando da atividade acusatória.

Este é o foro em que a forma deixará de ser garante de princípio, e assumirá as condições para a pretensão judicial de tutela de direito ofendido, seja a exercida pela própria vítima, seja aquela no qual o Estado assume tal tutela, o que ocorre somente em razão de fragilidade do sujeito ou interesse difuso envolvido.

A convalidação presta-se a esta seara precisamente por tratar-se de absorção da falha em virtude da supremacia de algum outro princípio envolvido. Nesta hipótese, abdicar-se-á da falha em nome da proteção ao acusado. Ademais, também se aceita o consentimento da vítima com o ato eivado de vício ou até mesmo suprimento da falha pelo representante do Ministério Público como causas que ilidiriam eventual saneamento ou nulidade.

Para alguns autores, seria exatamente neste ponto que seria cabível o conceito de nulidade relativa. Contudo, como já defendido neste trabalho, este conceito é indesejável por criar uma falsa correlação entre a nulidade do ato jurídico e do ato processual, ${ }^{48}$ além de constituir sintoma do sincretismo terminológico, o qual é aqui duramente combatido.

Sem prejuízo da representação do ofendido, o agente acusador deve ter em mente que se pautar em consonância com seus deveres de ofício reforça as próprias condições de legitimidade do Estado de Direito, entre estas até mesmo a dignidade e proteção do acusado.

\section{CONSIDERAÇÕES FINAIS}

À guisa de conclusão, vamos sintetizar em linhas gerais o que foi trabalhado neste ensaio.

Pugnamos que o processo penal de cunho constitucional deve pautar-se pelos ditames do garantismo e da acusatoriedade, de maneira a concretizar os auspícios de uma política criminal de minimalização da violência pública e privada. O processo penal estará investido do dever de efetivar a contenção do sistema penal, haja vista seu caráter de instrumentalidade garantista.

Tais pressupostos teóricos influenciam a teoria do ato inválido, principalmente pela exortação a orientar os requisitos legais à limitação do poder e à salvaguarda do imputado. Ademais, o referencial teórico também insta ao abandono da defesa de forma como valor em si, mas como um instrumento dentro do processo, conferindo uma desburocratização do sistema e uma aproximação dos funcionários ao público que tem o dever de servir, deixando de ser guardiões do sagrado rito.

Pudemos verificar também alguns elementos formadores da cultura judicial de nosso país, constatando, ao menos conforme nossa abordagem, a vigência de um inquisitório reformado, ou, eufe- 
misticamente, de um acusatório formal, o qual está indelevelmente arraigado na aplicação do quebrantamento formal, e que se caracteriza pela escrituralização, formalismo e prerrogativas instrutórias aos julgadores. Temos ainda, como agravante, a influência de uma teoria geral do processo civil, que cria paralelos entre o direito privado e o direito processual penal, com a conseqüente aplicação de categorias inadequadas ao processo penal, e que infestam a disciplina do ato inválido.

No segmento propositivo do trabalho, esboçamos a teoria de Binder, a qual foi amplamente detalhada em suas peculiaridades, e que prima - não é demais reiterar -, pela funcionalidade da forma. Esta teoria é tripartite, e tem como função mais magnânima a tutela do acusado, sendo seguida pela concessão de possibilidade de tutela judicial à vítima e pela regulação da atividade do Ministério Público. Sempre que houver contraposição de princípios, prevalecerá a proteção do réu.

\section{REFERENCIAS}

BINDER, Alberto. Introdução ao direito processual penal. Trad. de Fernando Zani. Rio de Janeiro: Lumen Juris, 2003. . El incumplimiento de las formas procesales: critica a la teoria unitaria de las nulidades. Buenos Aires: ADHOC, 2000.

CARNELUTTI, Francesco. As misérias do processo penal. São Paulo: Bookseller, 2001.
Por fim, cumpre dizer que este trabalho apenas objetiva uma ruptura com a tradição sobre nulidades, evitando criar idéias novas sem afastar-se do núcleo princípio lógico da teoria. Isto constituiria um exercício inócuo, vez que se acaba enxergando o nóvo com a perspectiva velha. A tarefa principal deste articulado é justamente tentar o inédito, sem a preocupação de pormenorizar e implementar a teoria de Binder.

Como diria Couture, é no processo penal onde o indivíduo encontra $a$ cidadela de sua inocência. A forma processual é o mecanismo que possibilitará a proteção dos inocentes, e a única maneira de assegurá-la está na estrutura processual criada com este propósito.

Destarte, a relevância deste trabalho está apenas no fomento a novos debates, de modo que se elaborem novas indagações na disciplina, que há tanto tempo se perpetua sem o imprescindível repensar crítico. A propositura de um novo enfoque é o maior contributo de nossa abordagem.

CARVALHO, Amilton Bueno e CARVALHO, Salo de. Reformas penais contemporâneas. Rio de Janeiro: Lumen Juris, 2005.

CARVALHO, Salo de. A ferida narcísica do direito penal. In: GAUER, Ruth (Org.) A qualidade do tempo: para além das aparências históricas. Rio de Janeiro: Lumen Juris, 2004. 
CARVALHO, Salo de. Pena e garantias. 2.ed. Rio de Janeiro: Lumen Juris, 2004.

COUTINHO, Jacinto Nelson de Miranda. Efetividade do processo penal e golpe de cena: um problema às reformas processuais. In: WUNDERLICH, Alexandre. Escritos de direito e processo penal em homenagem ao professor Paulo Tovo. Rio de Janeiro: Lumen Juris, 2002.

. Glosas a verdade, dúvida e certeza de Francesco Carnelutti, para os operadores do direito. In: SANCHEZ RUBIO, David, HERRERA FLORES, Joaquín e CARVALHO, Salo de (COORD). Anuário Ibero-americano de direitos humanos (2001/2002). Rio de Janeiro: Lumen Juris, 2002.

COUTINHO, Jacinto Nelson Miranda. O papel do novo juiz no processo penal. In: COUTINHO, J.N. Miranda (Coord.) Crítica à teoria geral do direito processual penal. Rio de Janeiro: Renovar, 2001.

DUCLERC, Emil. Provapenal e garantismo. uma investigação crítica sobre a verdade fática construída através do processo. Rio de Janeiro: Lumen Juris, 2004.

FERRAJOLI, Luigi. Direito e razão. São Paulo: Revista dos Tribunais, 2002.

FERRAJOLI, Luigi. Derechos y garantias: la ley del más débil. Traducción Perfecto Andrés Ibáñez. Madri: Trotta, 2001.

FOUCAULT, Michel. A verdade e as formas juridicas. 3.ed. Rio de Janeiro: Nau, 2003.
GRINOVER, Ada; CINTRA, Antônio Carlos de Araújo; DINAMARCO, Cândido Rangel. Teoria geral do processo. 20. ed. São Paulo: Malheiros, 2004.

GRINOVER, Ada, FERNANDES, Antonio Scarance; GOMES FILHO, Antonio Magalhães. Nulidades no processo penal. 7.ed. São Paulo: Revista dos Tribunais, 2001.

LOPES JÚNIOR, Aury. Introdução crítica ao processo penal: fundamentos da instrumentalidade garantista. Rio de Janeiro: Lumen Juris, 2004.

MAIER, Julio B.J. Función normativa de la nulidad. Buenos Aires: Depalma, 1980.

MORETTO, Rodrigo. Crítica interdisciplinar da pena de prisão. Rio de Janeiro: Lumen Juris, 2005.

MOSSIN, Heráclito Antônio. Nulidades no direito processual penal. São Paulo: Atlas, 1998.

PRADO, Geraldo. Sistema acusatório: a conformidade constitucional das leis processuais penais. 3.ed. Rio de Janeiro: Lumen Juris, 2005.

RANGEL, Paulo. Direito processual penal. 10. ed. Rio de Janeiro: Lumen Juris, 2005.

TOVO, Paulo Cláudio. Nulidades no processo penal brasileiro. Porto Alegre: Sérgio Antônio Fabris, 1988.

ZAFFARONI, Eugenio Raúl. Sistemas processuais na América Latina. 
